\title{
Koroner Arter Hastalarında Beslenme Alışkanlıklarının Kan Lipit Düzeylerine Etkisi
}

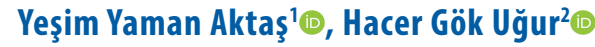

'Giresun Üniversitesi Sağlık Bilimleri Fakültesi, Cerrahi Hastalıkları Hemşireliği Anabilim Dalı, Giresun, Türkiye

${ }^{2}$ Ordu Üniversitesi Sağlık Bilimleri Fakültesi, Halk Sağlığı Hemşireliği Anabilim Dalı, Ordu, Türkiye

Yeşim Yaman Aktaş, Doç. Dr. Hacer Gök Uğur, Öğr. Gör. Dr.

Iletişim:

Doç. Dr. Yeşim Yaman Aktaş

Giresun Üniversitesi Sağlık Bilimleri Fakültesi, Cerrahi Hastalıkları Hemşireliği Anabilim Dalı, Giresun, Türkiye

E-Posta: yesimyaman28@hotmail.com

Gönderilme Tarihi : 09 Temmuz 2018

Revizyon Tarihi : 12 Kasım 2018

Kabul Tarihi : : 020 cak 2019
ÖZET

Amaç: Bu çalışma koroner arter hastalığı olan bireylerin beslenme alışkanlıklarının kan lipit düzeylerine etkisini belirlemek amacıyla yapııldı.

Çalışma Planı: Bu çalışma kesitsel tanımlayıcı olarak 01 Mart - 30 Mayıs 2016 tarihleri arasında bir eğitim ve araştırma hastanesinin kardiyoloji kliniğinde tedavi gören hastalar üzerinde yürütüldü. Örneklem büyüklüğünün hesaplanmasında $\mathrm{G}$ *Power 3.1.5 paket programı kullanıldı. Örneklem büyüklüğünü, $\% 95$ güven aralığı ve $\% 80$ evreni temsil etme yeteneği ile 105 hasta oluşturdu. Veriler araştırmacılar tarafından hazıılanan ve hastaların demografik özellikleri ve beslenme alışkanlıklarını içeren anket formu kullanılarak toplanmıştı. Verilerin değerlendirilmesinde tanımlayıı istatistikler ve ki-kare testi kullanıımıştır.

Bulgular: Araştırma kapsamındaki hastaların yaş ortalaması $66,66 \pm 10,77$ olup, $\% 58,1^{\prime i}$ erkektir. Katılımcıların ortalama total kolesterol değeri $175,83 \pm 42,68$, LDL kolesterol değeri $113,48 \pm 30,41$, HDL kolesterol değeri $44,53 \pm 17,95$ ve trigliserid değeri $139,76 \pm 60,93$ olarak bulundu. Çalışmada, düzenli ara öğün tüketme durumu ile trigliserid yüksekliği arasında istatistiksel olarak anlamlı bir ilişki olduğu belirlendi $(p<0,05)$. Süt-süt ürünleri ve hazır meyve suyu tüketimi ile LDL kolesterol yüksekliği, HDL kolesterol düşǚllüğü ve trigliserid yüksekliği arasında istatistiksel olarak anlamlı bir ilişki olduğu bulundu $(p<0,05)$. Ayrıca, balık tüketimi ile HDL kolesterol düşüklüğü ve asitli içecek tüketimi ile trigliserid yüksekliği arasında istatistiksel olarak anlamlı ilişki olduğu belirlendi $(p<0,05)$.

Sonuç: Bu araştıımada koroner arter hastalarında ara öğün tüketimi, süt ve süt ürünleri, hazır meyve suyu, asitli içecek ve balık tüketiminin kan lipit düzeylerini etkilediği bulundu. Bu bağlamda, koroner arter hastalığı açısından yüksek risk taşıyan bireylerin saptanması ve bu bireylere sağlıklı yaşam biçimi alışkanlıklarının kazandııııması için, risk faktörleri saptanarak değiştirilebilir olanların düzeltilmesine yönelik öneriler sunulabilir.

Anahtar sözcükler: Koroner arter hastalığı, beslenme, beslenme alışkanlığı, lipit düzeyleri

\section{THE EFFECTS OF NUTRITIONAL HABITS ON BLOOD LIPID LEVELS IN PATIENTS WITH CORONARY ARTERY DISEASE}

\section{ABSTRACT}

Aim: This study was conducted to determine the effects of nutritional habits on blood lipid levels in patients with coronary artery disease.

Study Design: This cross-sectional descriptive study was conducted on patients who were treated in a cardiology clinic of a training and research hospital between 1 March and 30 May 2016. The G*Power 3.1.5 package program was used to calculate the sample size. The sample size was 105 patients, with a $95 \%$ confidence interval and $80 \%$ ability to represent the universe. The data were collected using the questionnaire form prepared by the researchers, containing the demographic characteristics and nutritional habits of the patients. Descriptive statistics and chi-square test were used in the data analysis.

Results: The mean age of the patients was $66.66 \pm 10.77$ and $58.1 \%$ of the patients were male. The mean total cholesterol, LDL cholesterol, HDL cholesterol and triglyceride values of the participants in the study were found as $175.83 \pm 42.68,113.48 \pm 30.41$, $44.53 \pm 17.95$, and $139.76 \pm 60.93$, respectively. There was a statistically significant difference between regular snack consumption and increased triglycerides in the patients $(p<0.05)$. It was found that there was a statistically significant difference between the consumption of milk-dairy products and fruit juice in the patients and increased LDL cholesterol, decreased HDL cholesterol and increased triglyceride levels $(p<0.05)$. Moreover, the difference between fish consumption and decreased HDL cholesterol, and the consumption of acidic beverages and increased triglyceride levels were found to be statistically significant $(p<0.05)$.

Conclusion: In this study, it was found that regular snack consumption, consumption of milk and dairy products, fruit juice, acidic beverages and fish affected blood lipid levels in patients with coronary artery disease. In this context, it can be suggested that to identify individuals at high risk for coronary artery disease and to provide them with healthy lifestyle habits, risk factors can be identified and recommendations can be made to correct those that can be altered.

Keywords: coronary artery disease, nutrition, nutritional habits, blood lipid levels 
K alp ve damar hastalıkları; ortalama yaşam süresinin ve kalitesinin artmasına, korunma ve önleme çaışmalarına, tıbbi-cerrahi tanı ve tedavi yöntemlerindeki gelişmelere rağmen dünyada yaşamı tehdit eden önemli hastalıklar arasında birinci sıradaki yerini korumaktadır (1,2). 2012 yılında dünyada 17,3 milyon kişinin kalp damar hastalıkları nedeniyle öldüğü tahmin edilmektedir (3). Türkiye'de ise Kalp ve Damar Hastalıklarını Önleme ve Kontrol Programı Raporu'na göre (4), ölüm nedenlerinin temel hastalık gruplarına göre dağılımında ilk sırada kalp damar hastalıkları $(\% 47,7)$ yer almaktadır. Kalp damar hastalıkları içerisinde ölüme neden olan hastalıklardan birisi koroner arter hastalığıdır (KAH) (5).

Koroner arter hastalıklarının en sık rastlanan nedeni aterosklerozdur ve primer olarak arterlerin intima tabakası içinde kolesterol ve lipitlerin lokal toplanması ile karakterizedir. Ateroskleroz oluşumunu başlatan veya hızlandıran birçok risk faktörü vardır (6). Aterosklerozun gelişmesinde rol oynayan faktörler sıklıkla yaş, kalıtımsal faktörler, cinsiyet gibi değiştirilemeyen faktörler ile birlikte sigara ve alkol kullanımı, sistemik hastalıklar, obezite, sağlıksız beslenme, sedanter yaşam, yüksek dansiteli lipoprotein (HDL-K) düzeylerinin düşüklüğü, total ve düşük dansiteli lipoprotein (LDL-K) düzeylerinin yüksekliği gibi değiştirilebilen faktörlerdir (6-8). Kan kolesterol düzeyi 200 mg'ın üzerindeki bireylerde, her $50 \mathrm{mg}$ yükselme koroner arter hastalığı riskini \%36 ve HDL-K düzeyinin 35 mg'ın altında olması ise riski 1,54 oranında arttırmaktadır (9). Kanda LDL-K düzeyi yaş ve kilo ile artmakta, doymuş yağlardan ve kolesterolden zengin beslenme de serum LDL-K düzeyini yükseltmektedir (10).

KAH'a yol açan risk faktörlerinden obezite, diyabet, metabolik sendrom, hiperlipidemi ve hipertansiyon gelişimi sağlıklı beslenme ile geciktirilebilir veya azaltılabilir $(11,12)$. Ayrıca aşırı kalori alımı ve tuz tüketilmesinin önlenmesi, diyette hayvansal yağların azaltılarak bitkisel yağların tercih edilmesi, taze sebze, meyve, liften zengin yiyecekler ve balık tüketiminin artırılması $\mathrm{KAH}$ riskini azaltmaktadır (13). Bu bilgiler koruyucu önlemlerin çok daha etkin bir biçimde uygulanması gereğini ortaya koymaktadır. Bu hedeflere ulaşabilmek için koroner arter hastalıklarına yönelik risk faktörlerinin, bireylerin beslenme ve yaşam tarzı değişikliklerinin belirlenmesi gerekmektedir (12). Bu nedenle, bu çalışma koroner arter hastalığı olan bireylerin beslenme alışkanlıklarının kan lipit düzeylerine etkisini belirlemek amacıyla yapıldı.

\section{Gereç ve yöntem}

Bu çalışma kesitsel tanımlayıcı olarak 01 Mart-30 Mayıs 2016 tarihleri arasında bir eğitim ve araştırma hastanesinin kardiyoloji kliniğinde tedavi gören hastalar üzerinde yürütüldü. Araştırmanın evrenini, araştırmanın yürütüldüğü tarihlerde kardiyoloji kliniğinde tedavi gören koroner arter hastalığı olan bireyler oluşturdu ( $\mathrm{N}=259)$. Örneklem büyüklüğünün hesaplanmasında $G *$ Power 3.1.5 paket programı kullanıldı. Örneklem büyüklüğünü, $\% 95$ güven aralığı ve \%80 evreni temsil etme yeteneği ile 105 hasta oluşturdu. Hastaların araştırmaya alınma kriterleri; görme, işitme, anlama, konuşma problemi olmayan ve araştırmaya katılmayı kabul eden hastalar olarak belirlendi. Herhangi bir dışlama ölçütü kullanılmadı.

Araştırmanın verileri araştırmacılar tarafından hazırlanan ve hastaların demografik özellikleri ve beslenme alışkanlıklarını içeren anket formu kullanılarak toplandı. Araştırmacılar haftada üç gün klinikte bulundu ve veriler yüz yüze görüşme yöntemi ile araştırmacılar tarafından toplandı. Her bir hasta ile görüşme yaklaşık 15-20 dakika sürdü. Hastaların KAH oluşumunu kolaylaştırıcı faktörleri belirlemek için değerlendirilen total kolesterol, HDL-K, LDL-K ve trigliserid değerleri hasta dosyasından kayıt edildi.

Veriler SPSS (Statistical Package for Social Science for Windows) 20,0 istatistik paket programı kullanılarak değerlendirildi. Verilerin değerlendirilmesinde; tanımlayıcı istatistikler ve ki-kare testi kullanıldı. Kan lipit düzeylerinin değerlendirilmesinde; total kolesterol yüksekliği için TK düzeyi $>200 \mathrm{mg} / \mathrm{dL}, \mathrm{HDL}$ kolesterol düşüklüğü için HDL-K düzeyi $<40 \mathrm{mg} / \mathrm{dL}$, LDL kolesterol yüksekliği için LDL-K düzeyi $>130 \mathrm{mg} / \mathrm{dL}$ ve trigliserit yüksekliği için trigliserit düzeyi $>150 \mathrm{mg} / \mathrm{dL}$ değerleri esas alınmıştır (10). Araştırmada önemlilik düzeyi 0,05 olarak kabul edildi.

Araştırmanın uygulanabilmesi için araştırmanın uygulandığı eğitim ve araştırma hastanesinden yazılı izin ve etik kurul onayı (tarih: 29,02,2016, sayı: 49715540/050,01,04) alındı. Ayrıca araştırmaya katılan hastalardan sözel ve yazılı onamları alınarak araştırmaya gönüllü katıımları sağlandı. Araştırmaya katılan hastalar ile görüşülerek araştırmanın amacı ve araştırmadan sağlanacak yararlılıklar konusunda açıklamalar yapıldı. Ayrıca araştırmada isim belirtilmeyeceği, verecekleri bilgilerin gizli kalacağı ve araştırma dışında herhangi bir yerde kullanılamayacağına dair açıklama yapılarak, katılıp katılmama konusunda hiçbir baskı yapılmadan gönüllü katılım olduğu belirtildi. 


\section{Bulgular}

Araştırma kapsamındaki hastaların yaş ortalaması $66,66 \pm 10,77$ olup, $\% 58,1$ 'inin erkek, \%32,4'ünün okuryazar, \%21,9'unun emekli, \%63,8'inin gelir durumunun orta düzeyde olduğu ve $\% 53,3$ 'ünün ise yaşamında en uzun süre köyde yaşadığı saptandı. Katılımcıların \%66,7'sinin kronik bir hastalığının olduğu, \%25,7'sinin hipertansiyon hastalığı olduğu, \%90,5'inin sigara içtiği, \%98,1'inin alkol kullanmadığı, \%90,5'inin düzenli spor yapmadığı belirlendi. Katılımcıların \%74,3'ünün birinci derece akrabalarında kalp hastalığı olduğu, \%74,3'ünün lipit düşürücü tedavi kullandığı ve Beden Kitle Indeksi (BKi) ortalamasının $27,91 \pm 5,50 \mathrm{~kg} / \mathrm{m}^{2}$ olduğu bulundu (Tablo 1 ).

Araştırmada katılımcıların kan lipit düzeyleri dağılımı incelendiğinde; total kolesterol değeri $175,83 \pm 42,68 \mathrm{mg} /$ $\mathrm{dL}$, LDL-K değeri $113,48 \pm 30,41 \mathrm{mg} / \mathrm{dL}, \mathrm{HDL}-\mathrm{K}$ değeri $44,53 \pm 17,95 \mathrm{mg} / \mathrm{dL}$ ve trigliserid değeri $139,76 \pm 60,93$ $\mathrm{mg} / \mathrm{dL}$ olarak bulundu. Hastaların \%29,5'inde total kolesterol yüksekliği, \%21,9'unda LDL-K yüksekliği, \%49,5'inde HDL-K düşüklüğü ve \%31,4'ünde trigliserid yüksekliği olduğu saptandı (Tablo 2). Katılımcıların \%82,9'unun günde üç öğün yemek yediği, \%51,4'ünün öğün atladığı, $\% 84,8^{\prime}$ inin düzenli kahvaltı yaptığı, \%66,7'sinin düzenli öğle yemeği yediği, \%79'unun düzenli akşam yemeği yediği ve \%43,8'inin düzenli ara öğün tükettiği saptandı. Çalışmada, düzenli ara öğün tüketme durumları ile trigliserid yüksekliği arasında istatistiksel olarak anlamlı bir ilişki olduğu, düzenli ara öğün tüketen hastalarda trigliserid yüksekliğinin olduğu bulundu $(p<0,05)$. Diğer öğün düzenleri ile kan lipit düzeyleri arasında istatistiksel olarak anlamlı bir ilişki olmadığı belirlendi ( $p>0,05)$ (Tablo 3).

Katılımcıların \%17,1'inin kırmızı et, \%42,9'unun tavuk, \%23,8'inin balık, \%34,3'ünün kuru baklagilleri haftada bir kez tükettiği ve \%59'unun süt ve süt ürünlerini her gün tükettiği belirlendi (Tablo 4). Süt-süt ürünleri ve hazır meyve suyu tüketimi ile LDL-K yüksekliği, HDL-K düşüklüğü ve trigliserid yüksekliği arasında istatistiksel olarak anlamlı bir ilişki olduğu bulundu $(p<0,05)$. Balık tüketimi ile HDL-K düşüklüğü ve asitli içecek tüketimi ile trigliserid yüksekliği arasında istatistiksel olarak anlamlı ilişki olduğu saptandı $(p<0,05)$ (Tablo 5).

\section{Tartışma}

Koroner arter hastalığının önlenmesinde beslenme önemli bir rol oynar ve beslenme alışkanlıklarının düzenlenmesi hastalığın önlenmesinde önemli yaşam tarzı müdahaleleri arasında yer alır $(11,12)$. Hipertansiyon, diyabet, obezite ve hiperlipidemi dünya genelinde tüm ölümlerin nedeni

Tablo 1. Hastaların tanıııcı özelliklerinin dağıımı $(n=105)$ 
Tablo 2. Hastaların kan lipit düzeylerinin dağılımı

\begin{tabular}{|c|c|c|c|c|c|}
\hline Lipitler & $X \pm S S$ & & & $N$ & $\%$ \\
\hline $\mathrm{TK}, \mathrm{mg} / \mathrm{dL}$ & $\begin{array}{c}175,83 \pm 42,68 \\
\text { (Min: } 67,00-\text { Max: } 287,00)\end{array}$ & TK yüksekliği & $\begin{array}{l}\text { Yok } \\
\text { Var }\end{array}$ & $\begin{array}{l}74 \\
31\end{array}$ & $\begin{array}{l}70,5 \\
29,5\end{array}$ \\
\hline LDL-K, mg/dL & $\begin{array}{c}113,48 \pm 30,41 \\
\text { (Min: } 36,00-\text { Max: } 185,00 \text { ) }\end{array}$ & LDL-K yüksekliği & $\begin{array}{l}\text { Yok } \\
\text { Var }\end{array}$ & $\begin{array}{l}82 \\
23\end{array}$ & $\begin{array}{l}78,1 \\
21,9\end{array}$ \\
\hline $\mathrm{HDL}-\mathrm{K}, \mathrm{mg} / \mathrm{dL}$ & $\begin{array}{c}44,53 \pm 17,95 \\
\text { (Min: } 15,00 \text { - Max: 165,00) }\end{array}$ & HDL-K düşüklüğü & $\begin{array}{l}\text { Yok } \\
\text { Var }\end{array}$ & $\begin{array}{l}53 \\
52\end{array}$ & $\begin{array}{l}50,5 \\
49,5\end{array}$ \\
\hline $\mathrm{TG}, \mathrm{mg} / \mathrm{dL}$ & $\begin{array}{c}139,76 \pm 60,93 \\
\text { (Min: } 23,00-\text { Max: } 342,00 \text { ) }\end{array}$ & TG yüksekliği & $\begin{array}{l}\text { Yok } \\
\text { Var }\end{array}$ & $\begin{array}{l}72 \\
33\end{array}$ & $\begin{array}{l}68,6 \\
31,4\end{array}$ \\
\hline
\end{tabular}

TK, total kolesterol; LDL-K, LDL kolesterol; HDL-K, HDL kolesterol; TG, trigliserid.

Tablo 3. Hastaların öğün düzenleri ile kan lipit düzeylerinin karşısştırıması

\begin{tabular}{|c|c|c|c|c|c|c|c|c|c|c|}
\hline \multirow[b]{2}{*}{ Hastaların öğün düzenleri } & & & \multicolumn{2}{|c|}{ TK yüksekliği } & \multicolumn{2}{|c|}{ LDL-K yüksekliği } & \multicolumn{2}{|c|}{ HDL-K düşüklüğü } & \multicolumn{2}{|c|}{ TG yüksekliği } \\
\hline & & & Yok & Var & Yok & Var & Yok & Var & Yok & Var \\
\hline \multirow[t]{3}{*}{ Düzenli kahvaltı yapma } & Evet & $\mathrm{n}(\%)$ & $63(70,8)$ & $26(29,2)$ & $68(76,4)$ & $21(23,6)$ & $43(48,3)$ & $46(51,7)$ & $59(66,3)$ & $30(33,7)$ \\
\hline & Hayır & n (\%) & $11(6,8)$ & $5(31,2)$ & $14(87,5)$ & $2(12,5)$ & $10(62,5)$ & $6(37,5)$ & $13(81,2)$ & $3(18,8)$ \\
\hline & \multicolumn{2}{|c|}{ Test ve $p$ değeri } & \multicolumn{2}{|c|}{$X^{2}=0,027 ; p=0,869$} & \multicolumn{2}{|c|}{$X^{2}=0,976 ; p=0,323$} & \multicolumn{2}{|c|}{$X^{2}=1,092 ; p=0,296$} & \multicolumn{2}{|c|}{$X^{2}=1,408 ; p=0,235$} \\
\hline \multirow[t]{3}{*}{ Düzenli öğle yemeği yeme } & Evet & $\mathrm{n}(\%)$ & $49(70,0)$ & $21(30,0)$ & $51(72,9)$ & $19(27,1)$ & $38(54,3)$ & $32(45,7)$ & $50(71,4)$ & $20(28,6)$ \\
\hline & Hayır & $\mathrm{n}(\%)$ & $25(71,4)$ & $10(28,6)$ & $31(88,6)$ & $4(11,4)$ & $15(42,9)$ & $20(57,1)$ & $22(62,9)$ & $13(37,1)$ \\
\hline & \multicolumn{2}{|c|}{ Test ve $p$ değeri } & \multicolumn{2}{|c|}{$X^{2}=0,023 ; p=0,880$} & \multicolumn{2}{|c|}{$X^{2}=3,368 ; p=0,066$} & \multicolumn{2}{|c|}{$X^{2}=1,219 ; p=0,270$} & \multicolumn{2}{|c|}{$X^{2}=0,795 ; p=0,372$} \\
\hline \multirow[t]{3}{*}{ Düzenli akşam yemeği yeme } & Evet & $\mathrm{n}(\%)$ & $60(72,3)$ & $23(27,7)$ & $65(78,3)$ & $18(21,7)$ & $38(45,8)$ & $45(54,2)$ & $54(65,1)$ & $29(34,9)$ \\
\hline & Hayır & $\mathrm{n}(\%)$ & $14(63,6)$ & $8(36,4)$ & $17(77,3)$ & $5(22,7)$ & $15(68,2)$ & $7(31,8)$ & $18(81,8)$ & $4(18,2)$ \\
\hline & \multicolumn{2}{|c|}{ Test ve p değeri } & \multicolumn{2}{|c|}{$X^{2}=0,626 ; p=0,429$} & \multicolumn{2}{|c|}{$X^{2}=0,011 ; p=0,926$} & \multicolumn{2}{|c|}{$X^{2}=3,490 ; p=0,062$} & \multicolumn{2}{|c|}{$X^{2}=2,266 ; p=0,132$} \\
\hline \multirow[t]{3}{*}{ Düzenli ara öğün tüketimi } & Evet & $\mathrm{n}(\%)$ & $32(69,6)$ & $14(30,4)$ & $34(73,9)$ & $12(26,1)$ & $25(54,3)$ & $21(45,7)$ & $26(56,5)$ & $20(43,5)$ \\
\hline & Hayır & n (\%) & $42(71,2)$ & $17(28,8)$ & $48(81,4)$ & $11(18,6)$ & $28(47,5)$ & $31(52,5)$ & $46(78,0)$ & $13(22,0)$ \\
\hline & \multicolumn{2}{|c|}{ Test ve $p$ değeri } & \multicolumn{2}{|c|}{$X^{2}=0,033 ; p=0,857$} & \multicolumn{2}{|c|}{$X^{2}=0,837 ; p=0,360$} & \multicolumn{2}{|c|}{$X^{2}=0,491 ; p=0,484$} & \multicolumn{2}{|c|}{$X^{2}=5,515 ; p=0,019 *$} \\
\hline \multirow[t]{3}{*}{ Öğün atlama } & Evet & $\mathrm{n}(\%)$ & $36(66,7)$ & $18(33,3)$ & $45(83,3)$ & $9(16,7)$ & $28(51,9)$ & $26(48,1)$ & $37(68,5)$ & $17(31,5)$ \\
\hline & Hayır & n (\%) & $38(74,5)$ & $13(25,5)$ & $37(72,5)$ & $14(27,5)$ & $25(49,0)$ & $26(51,0)$ & $35(68,6)$ & $16(31,4)$ \\
\hline & \multicolumn{2}{|c|}{ Test ve $p$ değeri } & \multicolumn{2}{|c|}{$X^{2}=0,775 ; p=0,379$} & \multicolumn{2}{|c|}{$X^{2}=1,783 ; p=0,182$} & \multicolumn{2}{|c|}{$X^{2}=0,084 ; p=0,772$} & \multicolumn{2}{|c|}{$X^{2}=0,000 ; p=0,999$} \\
\hline
\end{tabular}

Tablo 4. Hastaların beslenme alışkanlıklarının dağıım

Tüketim Sıkı̆̆ı

\begin{tabular}{lcccccccc}
\hline & & Hiç & Her gün & Gün aşırı & Haftada bir & 15 günde bir & Ayda bir & Yılda bir \\
\hline Kırmııı et & $\mathrm{n}(\%)$ & $6(5,7)$ & $4(3,8)$ & $3(2,9)$ & $18(17,1)$ & $17(16,2)$ & $41(39,0)$ & $16(15,2)$ \\
Tavuk & $\mathrm{n}(\%)$ & $7(6,7)$ & $4(3,8)$ & $7(6,7)$ & $45(42,9)$ & $25(23,8)$ & $15(14,3)$ & $2(1,9)$ \\
Balık & $\mathrm{n}(\%)$ & $7(6,7)$ & $6(5,7)$ & $7(6,7)$ & $25(23,8)$ & $23(21,9)$ & $26(24,8)$ & $11(10,5)$ \\
Yumurta & $\mathrm{n}(\%)$ & $9(8,6)$ & $45(42,9)$ & $32(30,5)$ & $14(13,3)$ & $5(4,8)$ & - & - \\
Süt ve süt ürünleri & $\mathrm{n}(\%)$ & $3(2,9)$ & $62(59,0)$ & $31(29,5)$ & $5(4,8)$ & $3(2,9)$ & $1(1,0)$ & - \\
Kuru baklagiller & $\mathrm{n}(\%)$ & $8(7,6)$ & $9(8,6)$ & $27(25,7)$ & $36(34,3)$ & $12(11,4)$ & $9(8,6)$ & - \\
Hazır gıda & $\mathrm{n}(\%)$ & $57(54,3)$ & $2(1,9)$ & $3(2,9)$ & $8(7,6)$ & $5(4,8)$ & $30(28,6)$ & - \\
Hazır meyve suyu & $\mathrm{n}(\%)$ & $33(31,4)$ & $4(3,8)$ & $8(7,6)$ & $12(11,4)$ & $9(8,6)$ & $22(21,0)$ & $17(16,2)$ \\
Asitli içecek & $\mathrm{n}(\%)$ & $57(54,3)$ & $2(1,9)$ & $4(3,8)$ & $7(6,7)$ & $4(3,8)$ & $15(14,3)$ & $16(15,2)$
\end{tabular}


Tablo 5. Hastaların beslenme alışkanlıkları ile kan lipit düzeylerinin karşılaştııımas

\begin{tabular}{|c|c|c|c|c|c|c|c|c|c|c|}
\hline \multirow[t]{2}{*}{ Tüketilen Besinler } & & & \multicolumn{2}{|c|}{ TK yüksekliği } & \multicolumn{2}{|c|}{ LDL-K yüksekliği } & \multicolumn{2}{|c|}{ HDL-K düşüklüğü } & \multicolumn{2}{|c|}{ TG yüksekliği } \\
\hline & & & Yok & Var & Yok & Var & Yok & Var & Yok & Var \\
\hline Kırmızı et & $\begin{array}{l}\text { Hiç } \\
\text { Her gün } \\
\text { Gün aşırı } \\
\text { Haftada bir } \\
15 \text { günde bir } \\
\text { Ayda bir } \\
\text { Yılda bir }\end{array}$ & $\begin{array}{l}\mathrm{n}(\%) \\
\mathrm{n}(\%) \\
\mathrm{n}(\%) \\
\mathrm{n}(\%) \\
\mathrm{n}(\%) \\
\mathrm{n}(\%) \\
\mathrm{n}(\%) \\
\end{array}$ & $\begin{array}{c}4(66,7) \\
3(75,0) \\
2(66,7) \\
14(77,8) \\
11(64,7) \\
29(70,7) \\
11(68,8) \\
\end{array}$ & $\begin{array}{c}2(33,3) \\
1(25,0) \\
1(33,3) \\
4(22,2) \\
6(35,3) \\
12(29,3) \\
5(31,2) \\
\end{array}$ & $\begin{array}{c}5(83,3) \\
4(100,0) \\
3(100,0) \\
16(88,9) \\
14(82,4) \\
28(68,3) \\
12(75,0) \\
\end{array}$ & $\begin{array}{c}1(16,7) \\
- \\
- \\
2(11,1) \\
3(17,6) \\
13(31,7) \\
4(25,0) \\
\end{array}$ & $\begin{array}{c}2(33,3) \\
2(50,0) \\
3(100,0) \\
9(50,0 ”) \\
7(41,2) \\
23(56,1) \\
7(43,8) \\
\end{array}$ & $\begin{array}{c}4(66,7) \\
2(50,0) \\
- \\
9(50,0) \\
10(58,8) \\
18(43,9) \\
9(56,2) \\
\end{array}$ & $\begin{array}{c}3(50,0) \\
3(75,0) \\
2(66,7) \\
17(94,4) \\
10(58,8) \\
28(68,3) \\
9(56,2)\end{array}$ & $\begin{array}{c}3(50,0) \\
1(25,0) \\
1(33,3) \\
1(5,6) \\
7(41,2) \\
13(31,7) \\
7(43,8) \\
\end{array}$ \\
\hline Test ve p değeri & & & \multicolumn{2}{|c|}{$X^{2}=0,860 ; p=0,990$} & \multicolumn{2}{|c|}{$X^{2}=5,858 ; p=0,439$} & \multicolumn{2}{|c|}{$X^{2}=5,047 ; p=0,538$} & \multicolumn{2}{|c|}{$X^{2}=8,511 ; p=0,203$} \\
\hline Tavuk & $\begin{array}{c}\text { Hiç } \\
\text { Her gün } \\
\text { Gün aşırı } \\
\text { Haftada bir } \\
15 \text { günde bir } \\
\text { Ayda bir } \\
\text { YIlda bir }\end{array}$ & $\begin{array}{l}\mathrm{n}(\%) \\
\mathrm{n}(\%) \\
\mathrm{n}(\%) \\
\mathrm{n}(\%) \\
\mathrm{n}(\%) \\
\mathrm{n}(\%) \\
\mathrm{n}(\%)\end{array}$ & $\begin{array}{c}4(57,1) \\
4(100,0) \\
6(85,7) \\
28(62,2) \\
18(72,0) \\
12(80,0) \\
2(100,0)\end{array}$ & $\begin{array}{c}3(42,9) \\
- \\
1(14,3) \\
17(37,8) \\
7(28,0) \\
3(20,0) \\
-\end{array}$ & $\begin{array}{c}6(85.7) \\
4(100.0) \\
5(71.4) \\
33(73.3) \\
20(80.0) \\
12(80.0) \\
2(100.0)\end{array}$ & $\begin{array}{c}1(14,3) \\
- \\
2(28,6) \\
12(26,7) \\
5(20,0) \\
3(20,0) \\
-\end{array}$ & $\begin{array}{c}3(42,9) \\
2(50,0) \\
4(57,1) \\
19(42,2) \\
15(60,0) \\
10(66,7) \\
- \\
\end{array}$ & $\begin{array}{c}4(57,1) \\
2(50,0) \\
3(42,9) \\
26(57,8) \\
10(40,0) \\
5(33,3) \\
2(100,0)\end{array}$ & $\begin{array}{c}5(71,4) \\
2(50,0) \\
7(100,0) \\
30(66,7) \\
17(68,0) \\
11(73,3) \\
- \\
\end{array}$ & $\begin{array}{c}2(28,6) \\
2(50,0) \\
- \\
15(33,3) \\
8(32,0) \\
4(26,7) \\
100,0 \\
\end{array}$ \\
\hline Test ve p değeri & & & \multicolumn{2}{|c|}{$X^{2}=6,048 ; p=0,418$} & \multicolumn{2}{|c|}{$X^{2}=2,784 ; p=0,835$} & \multicolumn{2}{|c|}{$X^{2}=6,032 ; p=0,420$} & \multicolumn{2}{|c|}{$X^{2}=8,476 ; p=0,205$} \\
\hline Balık & $\begin{array}{c}\text { Hiç } \\
\text { Her gün } \\
\text { Gün aşırı } \\
\text { Haftada bir } \\
15 \text { günde bir } \\
\text { Ayda bir } \\
\text { YIlda bir }\end{array}$ & $\begin{array}{l}\mathrm{n}(\%) \\
\mathrm{n}(\%) \\
\mathrm{n}(\%) \\
\mathrm{n}(\%) \\
\mathrm{n}(\%) \\
\mathrm{n}(\%) \\
\mathrm{n}(\%)\end{array}$ & $\begin{array}{c}5(71,4) \\
4(66,7) \\
4(57,1) \\
16(64,0) \\
15(65,2) \\
21(80,8) \\
9(81,8)\end{array}$ & $\begin{array}{l}2(28,6) \\
2(33,3) \\
3(42,9) \\
9(36,0) \\
8(34,8) \\
5(19,2) \\
2(18,2)\end{array}$ & $\begin{array}{c}7(100,0) \\
5(83,3) \\
5(71,4) \\
19(76,0) \\
15(65,2) \\
22(84,6) \\
9(81,8)\end{array}$ & $\begin{array}{c}- \\
1(16,7) \\
2(28,6) \\
6(24,0) \\
8(34,8) \\
4(15,4) \\
2(18,2)\end{array}$ & $\begin{array}{c}1(14,3) \\
5(83,3) \\
4(57,1) \\
11(44,0) \\
8(34,8) \\
17(65,4) \\
7(63,6)\end{array}$ & $\begin{array}{c}6(85,7) \\
1(16,7) \\
3(42,9) \\
14(56,0) \\
15(65,2) \\
9(34,6) \\
4(36,4)\end{array}$ & $\begin{array}{c}5(71,4) \\
5(83,3) \\
4(57,1) \\
17(68,0) \\
11(47,8) \\
21(80,8) \\
9(81,8)\end{array}$ & $\begin{array}{c}2(28,6) \\
1(16,7) \\
3(42,9) \\
8(32,0) \\
12(52,2) \\
5(19,2) \\
2(18,2)\end{array}$ \\
\hline Test ve p değeri & & & \multicolumn{2}{|c|}{$X^{2}=3,457 ; p=0,750$} & \multicolumn{2}{|c|}{$X^{2}=5,271 ; p=0,510$} & \multicolumn{2}{|c|}{$X^{2}=12,863 ; p=0,045$} & \multicolumn{2}{|c|}{$X^{2}=8,345 ; p=0,214$} \\
\hline Yumurta & $\begin{array}{c}\text { Hiç } \\
\text { Her gün } \\
\text { Gün aşırı } \\
\text { Haftada bir } \\
15 \text { günde bir }\end{array}$ & $\begin{array}{l}\mathrm{n}(\%) \\
\mathrm{n}(\%) \\
\mathrm{n}(\%) \\
\mathrm{n}(\%) \\
\mathrm{n}(\%)\end{array}$ & $\begin{array}{c}5(55,6) \\
32(71,1) \\
21(65,6) \\
11(78,6) \\
5(100,0)\end{array}$ & $\begin{array}{c}4(44,4) \\
13(28,9) \\
11(34,4) \\
3(21,4) \\
-\end{array}$ & $\begin{array}{c}7(77,8) \\
33(73,3) \\
25(78,1) \\
12(85,7) \\
5(100,0)\end{array}$ & $\begin{array}{c}2(22,2) \\
12(26,7) \\
7(21,9) \\
2(14,3) \\
-\end{array}$ & $\begin{array}{c}3(33,3) \\
24(53,3) \\
17(53,1) \\
7(50,0) \\
2(40,0)\end{array}$ & $\begin{array}{c}6(66,7) \\
21(46,7) \\
15(46,9) \\
7(50,0) \\
3(60,0)\end{array}$ & $\begin{array}{c}8(88,9) \\
32(71,1) \\
17(53,1) \\
11(78,6) \\
4(80,0)\end{array}$ & $\begin{array}{c}1(11,1) \\
13(28,9) \\
15(46,9) \\
3(21,4) \\
1(20,0)\end{array}$ \\
\hline Test ve p değeri & & & \multicolumn{2}{|c|}{$X^{2}=3,869 ; p=0,424$} & \multicolumn{2}{|c|}{$X^{2}=2,47 ; p=0,649$} & \multicolumn{2}{|c|}{$X^{2}=1,516 ; p=0,824$} & \multicolumn{2}{|c|}{$X^{2}=6,354 ; p=0,174$} \\
\hline Süt ve süt ürünleri & $\begin{array}{l}\text { Hiç } \\
\text { Her gün } \\
\text { Gün aşırı } \\
\text { Haftada bir } \\
15 \text { günde bir } \\
\text { Ayda bir }\end{array}$ & $\begin{array}{l}\mathrm{n}(\%) \\
\mathrm{n}(\%) \\
\mathrm{n}(\%) \\
\mathrm{n}(\%) \\
\mathrm{n}(\%) \\
\mathrm{n}(\%)\end{array}$ & $\begin{array}{c}1(33,3) \\
46(74,2) \\
22(71,0) \\
3(60,0) \\
1(33,3) \\
1(100,0)\end{array}$ & $\begin{array}{c}2(66,7) \\
16(25,8) \\
9(29,0) \\
2(40,0) \\
2(66,7) \\
-\end{array}$ & $\begin{array}{c}2(66,7) \\
49(79,0) \\
25(80,6) \\
5(100,0) \\
- \\
1(100,0)\end{array}$ & $\begin{array}{c}1(33,3) \\
13(21,0) \\
6(19,4) \\
- \\
3(100,0) \\
-\end{array}$ & $\begin{array}{c}1(33,3) \\
33(53,2) \\
16(51,6) \\
- \\
3(100,0) \\
-\end{array}$ & $\begin{array}{c}2(66,7) \\
29(46,8) \\
15(48,4) \\
5(100,0) \\
- \\
1(100,0)\end{array}$ & $\begin{array}{c}2(66,7) \\
47(75,8) \\
18(58,1) \\
1(20,0) \\
3(100,0) \\
1(100,0)\end{array}$ & $\begin{array}{c}1(33,3) \\
15(24,2) \\
13(41,9) \\
4(80,0) \\
- \\
-\end{array}$ \\
\hline Test ve p değeri & & & \multicolumn{2}{|c|}{$X^{2}=5,076 ; p=0,407$} & \multicolumn{2}{|c|}{$X^{2}=12,757 ; p=0,026$} & \multicolumn{2}{|c|}{$X^{2}=13,097 ; p=0,022$} & \multicolumn{2}{|c|}{$X^{2}=11,125 ; p=0,049$} \\
\hline Kuru baklagiller & $\begin{array}{c}\text { Hiç } \\
\text { Her gün } \\
\text { Gün aşırı } \\
\text { Haftada bir } \\
15 \text { günde bir } \\
\text { Ayda bir }\end{array}$ & $\begin{array}{l}\mathrm{n}(\%) \\
\mathrm{n}(\%) \\
\mathrm{n}(\%) \\
\mathrm{n}(\%) \\
\mathrm{n}(\%) \\
\mathrm{n}(\%)\end{array}$ & $\begin{array}{c}3(37,5) \\
7(77,8) \\
23(85,2) \\
24(66,7) \\
7(58,3) \\
7(77,8)\end{array}$ & $\begin{array}{c}5(62,5) \\
2(22,2) \\
4(14,8) \\
12(33,3) \\
5(41,7) \\
2(22,2) \\
\end{array}$ & $\begin{array}{c}5(62,5) \\
7(77,8) \\
24(88,9) \\
28(77,8) \\
7(58,3) \\
8(88,9)\end{array}$ & $\begin{array}{l}3(37,5) \\
2(22,2) \\
3(11,1) \\
8(22,2) \\
5(41,7) \\
1(11,1) \\
\end{array}$ & $\begin{array}{c}4(50,0) \\
5(55,6) \\
16(59,3) \\
20(55,6) \\
5(41,7) \\
2(22,2)\end{array}$ & $\begin{array}{c}4(50,0) \\
4(44,4) \\
11(40,7) \\
16(44,4) \\
7(58,3) \\
7(77,8)\end{array}$ & $\begin{array}{c}4(50,0) \\
7(77,8) \\
18(66,7) \\
28(77,8) \\
7(58,3) \\
6(66,7) \\
\end{array}$ & $\begin{array}{l}4(50,0) \\
2(22,2) \\
9(33,3) \\
8(22,2) \\
5(41,7) \\
3(33,3)\end{array}$ \\
\hline Test ve p değeri & & & \multicolumn{2}{|c|}{$X^{2}=8,590 ; p=0,198$} & \multicolumn{2}{|c|}{$X^{2}=6,354 ; p=0,385$} & \multicolumn{2}{|c|}{$X^{2}=5,584 ; p=0,471$} & \multicolumn{2}{|c|}{$X^{2}=4,334 ; p=0,632$} \\
\hline Hazır gıda & $\begin{array}{c}\text { Hiç } \\
\text { Her gün } \\
\text { Gün aşırı } \\
\text { Haftada bir } \\
15 \text { günde bir }\end{array}$ & $\begin{array}{l}n(\%) \\
n(\%) \\
n(\%) \\
n(\%) \\
n(\%)\end{array}$ & $\begin{array}{c}41(71,9) \\
1(50,0) \\
3(100,0) \\
4(50,0) \\
5(100,0)\end{array}$ & $\begin{array}{c}16(28.1) \\
1(50.0) \\
- \\
4(50.0) \\
-\end{array}$ & $\begin{array}{c}44(77,2) \\
1(50,0) \\
3(100,0) \\
7(87,5) \\
5(100,0)\end{array}$ & $\begin{array}{c}13(22,8) \\
1(50,0) \\
- \\
1(12,5) \\
-\end{array}$ & $\begin{array}{c}28(49,1) \\
2(100,0) \\
- \\
4(50,0) \\
4(80,0)\end{array}$ & $\begin{array}{c}29(50,9) \\
- \\
3(100,0) \\
4(50,0) \\
1(20,0)\end{array}$ & $\begin{array}{c}43(75,4) \\
1(50,0) \\
2(66,7) \\
4(50,0) \\
4(80,0)\end{array}$ & $\begin{array}{c}14(24,6) \\
1(50,0) \\
1(33,3) \\
4(50,0) \\
1(20,0)\end{array}$ \\
\hline Test ve p değeri & & & \multicolumn{2}{|c|}{$X^{2}=5,634 ; p=0,344$} & \multicolumn{2}{|c|}{$X^{2}=4,005 ; p=0,549$} & \multicolumn{2}{|c|}{$X^{2}=6,809 ; p=0,235$} & \multicolumn{2}{|c|}{$X^{2}=4,178 ; p=0,524$} \\
\hline Hazır meyve suyu & $\begin{array}{c}\text { Hiç } \\
\text { Her gün } \\
\text { Gün aşırı } \\
\text { Haftada bir } \\
15 \text { günde bir } \\
\text { Ayda bir }\end{array}$ & $\begin{array}{l}\mathrm{n}(\%) \\
\mathrm{n}(\%) \\
\mathrm{n}(\%) \\
\mathrm{n}(\%) \\
\mathrm{n}(\%) \\
\mathrm{n}(\%)\end{array}$ & $\begin{array}{c}25(75,8) \\
3(75,0) \\
7(87,5) \\
7(58,3) \\
7(77,8) \\
16(72,7)\end{array}$ & $\begin{array}{l}8(24,2) \\
1(25,0) \\
1(12,5) \\
5(41,7) \\
2(22,2) \\
6(27,3)\end{array}$ & $\begin{array}{c}29(87,9) \\
3(75,0) \\
5(62,5) \\
9(75,0) \\
9(100,0) \\
12(54,5)\end{array}$ & $\begin{array}{c}4(12,1) \\
1(25,0) \\
3(37,5) \\
3(25,0) \\
- \\
10(45,5)\end{array}$ & $\begin{array}{c}17(51,5) \\
4(100,0) \\
6(75,0) \\
4(33,3) \\
6(66,7) \\
11(50,0)\end{array}$ & $\begin{array}{c}16(48,5) \\
- \\
2(25,0) \\
8(66,7) \\
3(33,3) \\
11(50,0)\end{array}$ & $\begin{array}{c}17(51,5) \\
4(100,0) \\
6(75,0) \\
9(75,0) \\
7(77,8) \\
20(90,9)\end{array}$ & $\begin{array}{c}16(48,5) \\
- \\
2(25,0) \\
3(25,0) \\
2(22,2) \\
2(9,1)\end{array}$ \\
\hline Test ve p değeri & & & \multicolumn{2}{|c|}{$X^{2}=13,752 ; p=0,033$} & $X^{2}=13,00$ & $=0,043$ & $X^{2}=14,04$ & $p=0,029$ & $X^{2}=13,752$ & $p=0,033$ \\
\hline Asitli içecek & $\begin{array}{c}\text { Hiç } \\
\text { Her gün } \\
\text { Gün aşırı } \\
\text { Haftada bir } \\
15 \text { günde bir } \\
\text { Ayda bir }\end{array}$ & $\begin{array}{l}\mathrm{n}(\%) \\
\mathrm{n}(\%) \\
\mathrm{n}(\%) \\
\mathrm{n}(\%) \\
\mathrm{n}(\%) \\
\mathrm{n}(\%)\end{array}$ & $\begin{array}{c}42(73,7) \\
1(50,0) \\
3(75,0) \\
5(71,4) \\
4(100,0) \\
9(60,0)\end{array}$ & $\begin{array}{c}15(26,3) \\
1(50,0) \\
1(25,0) \\
2(28,6) \\
- \\
6(40,0)\end{array}$ & $\begin{array}{c}46(80,7) \\
2(100,0) \\
4(100,0) \\
5(71,4) \\
4(100,0) \\
11(73,3)\end{array}$ & $\begin{array}{c}11(19,3) \\
- \\
- \\
2(28,6) \\
- \\
4(26,7)\end{array}$ & $\begin{array}{c}26(45,6) \\
1(50,0) \\
2(50,0) \\
6(85,7) \\
2(50,0) \\
7(46,7)\end{array}$ & $\begin{array}{c}31(54,4) \\
1(50,0) \\
2(50,0) \\
1(14,3) \\
2(50,0) \\
8(53,3)\end{array}$ & $\begin{array}{c}40(70,2) \\
- \\
4(100,0) \\
7(100,0) \\
4(100,0) \\
10(66,7)\end{array}$ & $\begin{array}{c}17(29,8) \\
2(100,0) \\
- \\
- \\
- \\
5(33,3)\end{array}$ \\
\hline
\end{tabular}


olarak en büyük 10 risk faktöründen dördünü temsil etmektedir. Bu risk faktörleri kalp damar hastalıklarının gelişmesinde beslenmenin hayati rolünü vurgulamaktadır (12).

Koroner arter hastalığı için önemli risk faktörlerinden birisi obezitedir. Bu çalışmada hastaların BKI ortalamasının $27,91 \pm 5,50 \mathrm{~kg} / \mathrm{m}^{2}$ olduğu ve BKI gruplamasına göre hastaların kilolu grupta yer aldığı saptandı. Yaklaşık 25,000 kişinin tarandığı TOHTA (Türkiye Obezite ve Hipertansiyon taraması) araştırmasında ise BKi'ye göre obezite insidansı kadınlarda \%36, erkeklerde \%17 ve toplamda \%25 olarak bulunmuştur (14). Obezite kalp damar hastalıkları için bağımsız bir risk faktörüdür. Obezite ile hipertansiyon, glikoz intoleransı, LDL-K ve trigliserid yüksekliği sıklıkla birlikte görüldüğünden $\mathrm{KAH}$ riskini artırmaktadır (11). Finlandiya'da 16113 kadın ve erkek üzerinde yapılan ve 15 yıl izleme dayanan bir çalışmada, her iki cinsiyette de BKi arttıkça koroner arter hastalıkları için mortalitenin arttığı belirlenmiştir (15). Çıkım ve ark. çalışmalarında, BKi değerlerinin $30 \mathrm{~kg} / \mathrm{m}^{2 \prime}$ nin üzerinde olması ve abdominal obezite ile kardiyovasküler risk göstergeleri arasında anlamlı bir ilişki bulmuştur (16). Çalışma bulgularımız literatür ile benzerlik göstermekte olup, araştırma kapsamındaki hastaların kilolu grupta yer aldığı görülmektedir. Bu nedenle, BKi yüksek olan koroner arter hastalığı olan bireylerin takiplerinde beden ağırlıkları değerlendirilmeli ve diyetleri önerilen kalori ihtiyaçlarına göre düzenlenmelidir.

Koroner arter hastalığı gelişmesinde rol oynayan değiştirilebilir risk faktörlerinden birisi de fiziksel aktivitedir. Fiziksel aktivite, haftada en az 3-4 gün düzenli olarak, yarım saati aşan sürelerde, hızlı yürüme, merdiven çıkma, bisiklete binme, dans etme ve benzeri, orta şiddette, büyük kas gruplarının ardı sıra kasılıp gevşemesini sağlayan her türlü dinamik aerobik aktivitedir (17). Çalışmada katılımcıların \%90,5'inin düzenli spor yapmadığı belirlenmiştir. Çalışma bulgularımıza benzer şekilde, Erenay ve Oğuz çalışmalarında akut koroner sendromlu hastaların fiziksel aktivitelerini incelemiş ve olguların \%65'inin hareketsiz olduğunu saptamıştır (18). Türkiye ile Avrupa'nın karşılaştırıldığı bir diğer çalışmada, Uluslar arası Fiziksel Aktivite Anketi (IPAQ) sınıflamasına göre düşük fiziksel aktivite oranı $(\% 54,5$ ve $\% 23,1)$ en yüksek ve yoğun fiziksel aktivite oranı en düşük $(\% 10,5$ ve $\% 39,4)$ ülke Türkiye olarak bulunmuştur (19). Lakusic ve ark.'nın üç haftalık kardiyak rehabilitasyon programının KAH'ı olan hastaların kan lipitleri üzerindeki etkisini araştırdıkları çalışmalarında ise; rehabilitasyon sonrasında statin kullanmayan, kolesterol düzeyleri yüksek olan hastaların total ve LDL-K düzeylerinde sırasıyla $\% 16, \% 17$, trigliserit düzeylerinde
\%15 azalma, HDL-K düzeylerinde ise \%9 artış olduğunu belirlemişlerdir (20). Literatürde yer alan çalışmalar, fiziksel aktivitenin $\mathrm{KAH}$ risk faktörlerinin önlenmesinde ve kontrolünde önemli bir etken olduğunu göstermektedir. Bu bağlamda, araştırmada hastaların düşük fiziksel aktivite düzeylerinin kan lipit düzeylerini etkileyebileceği söylenebilir.

Kan lipit düzeyleri ile KAH arasında lineer bir ilişki mevcuttur ve kan lipit düzeyleri değiştirilebilen risk faktörleri arasında yer almaktadır $(21,22)$. Günümüzde kan lipit düzeylerini düşürmeye yönelik müdahaleler ile $\mathrm{KAH}$ riskinin önemli ölçüde azaldığı gösterilmiştir (22). Bu çalışmada katılımcıların \%29,5'inde total kolesterol yüksekliği, \%21,9'unda LDL-K yüksekliği, \%49,5'inde HDL-K düşüklüğü ve \%31,4'ünde trigliserid yüksekliği saptanmıştır. Çalışma bulgularımıza benzer şekilde, Abraham çalışmasında serum total kolesterol ve trigliserid düzeylerindeki artış ile ateroskleroz ve $\mathrm{KAH}$ arasında anlamlı bir ilişki saptamıştır (21). Kan lipit düzeyleri diyet, obezite, egzersiz, stres, sigara ve alkol tüketimi, diyabet ve hipotiroidizm gibi kronik hastalıklara bağlı değişkenlik göstermektedir (21). Özellikle tereyağı, sığır eti, hindistan cevizi yağı gibi doymuş yağ asitlerinden zengin diyet kan lipit düzeylerini artırır. Kan lipit düzeyi beslenme alışkanlıklarının düzeltilmesi, fiziksel aktivite ve medikal tedaviyle azaltılabilir. Ayrıca diyette doymuş yağ tüketiminin azaltılması hiperlipideminin yönetiminde etkili olabilir $(22,23)$.

Araştırma kapsamındaki hastaların öğün düzenleri incelendiğinde; \%82,9'unun günde üç öğün yemek yediği, \%51,4'ünün öğün atladığı, \%84,8'inin düzenli kahvaltı yaptığı, \%66,7'sinin düzenli öğle yemeği yediği, \%79'unun düzenli akşam yemeği yediği ve \%43,8'inin düzenli ara öğün tükettiği saptandı. Szoeke ve ark., kadınların kalp damar hastalıkları yönünden değiştirilebilir risk faktörlerini incelediği çalışmasında, katılımcıların \%52,6'sının düzenli kahvaltı yaptığını belirtmiştir (24). Kahvaltı sıklıkla günün en önemli öğünü olarak bildirilmekle birlikte, kahvaltı ve öğle yemeği alışkanlığı prevelansı son 40 yılda en büyük düşüşü göstermiştir (25). Düzenli kahvaltı alışkanlığındaki azalma, obezite ve kalp damar hastalıkları prevelansında artışa neden olmaktadır $(26,27)$. Kesitsel araştırmalarda, düzenli kahvaltı yapan bireylerde kalp damar hastalıkları yönünden risk faktörleri olan yüksek LDL-K, düşük HDL-K ve yüksek trigliserid değerleri daha düşük oranda saptanmıştır $(27,28)$. Bu çalışmada düzenli kahvaltı alışkanlığı literatür bulgularına göre daha yüksek olmakla birlikte, düzenli kahvaltı alışkanlığı ile kan lipit düzeyleri arasında anlamlı bir ilişki bulunamamıştır. 
Bireylerin öğün düzenleri giderek çeşitlilik göstermektedir. Günümüzde öğün atlama ve atıştırma alışkanlıklarının daha yaygın hale gelmesiyle kahvaltı, öğle ve akşam yemeklerini ayırt etmek zor hale gelmiştir. Yaygın hale gelen bu tip beslenme alışkanlıkları kardiyometabolik sağlık göstergeleri olan obezite, kan lipit düzeyleri, insülin direnci ve kan basıncı üzerinde çeşitli etkilere neden olmaktadır (22). Bu araştırmada düzenli ara öğün tüketen hasta grubunda trigliserid yüksekliğinin olduğu, ancak hastaların diğer öğün düzenleri ile kan lipit düzeyleri arasında anlamlı bir ilişki olmadığı bulundu. Araştırmalar, öğün sıklığının değiştirilmesinin trigliserid konsantrasyonları üzerinde belirgin bir etkisinin bulunmadığını ortaya koymaktadır $(29,30)$. Yapılan çalışmalarda öğün sıklığına bağlı trigliserid düzeylerinde azalma olduğu belirtilmesine rağmen, trigliserid değerlerindeki düşüşün bazal değerler ile karşılaştııılığında istatistiksel olarak anlamlı olmadığı saptanmıştır $(30,31)$. Çalışma bulgularımızın aksine, Titan ve ark. tarafından yapılan kesitsel çalışmada öğün sıklığı fazla olan bireylerin total kolesterol ve LDL-K değerlerinin daha düşük olduğu, ancak HDL-K değerinin öğün sıklığından etkilenmediği bulunmuştur (32). Aynı çalışmada yeme alışkanlığı günde 6 öğün olan bireylerin total kolesterol düzeylerinin, öğün sıklığı 1 ya da 2 olan bireylere göre $0,15 \mathrm{mmol} / \mathrm{L}$ 'den daha düşük olduğu belirlenmiştir. Araştırma bulgularımızın literatür ile çelişkili olmasının nedeni, araştırma kapsamındaki hastaların büyük çoğunluğunun kronik hastalığı olması ve BKi'nin yüksek olması ile ilişkilendirilebilir.

Bu çalışmada hastaların diyetinde tavuk ve kuru baklagilleri daha fazla tükettiği, kırmızı et ve balığın daha az tüketildiği bulundu. Ayrıca balık tüketiminin haftada bir ya da 15 günde bir olduğu hasta grubunda HDL-K değerlerinin düşük olduğu saptandı. Arslan ve ark., genel beslenme örüntüsünü inceledikleri TEKHARF çalışmasında, hastaların farklı besin gruplarından protein alımını incelemiş ve ilk sırada tahıllar (\%37) ve daha sonra kırmızı et ve tavuk (\%20), süt ve süt ürünlerinin (\%19) yer aldığını belirtmiştir (33). Aynı çalışmada protein alımı açısından kuru baklagiller (\%3), yumurta (\%4), balık (\%1) ve yağlı tohumların (\%1) çok az tüketildiği saptanmıştır. Bu çalışmada, literatür bulgularına benzer şekilde balık tüketiminin çok az olduğu, ancak kuru baklagil tüketiminin daha fazla olduğu görülmektedir. Özellikle kalp sağlığını korumak için balıkta bulunan omega-3 yağ asidi alınmalıdır. Omega-3 yağ asitleri içeren balık, kalp damar hastalıklarına karşı koruyucu olan HDL-K düzeyinde artış sağlamaktadır (34). Bu nedenle AHA'nın önerilerine göre çoklu doymamış omega-3 yağ asidi içerdiği için haftada en az 2 kez balık tüketilmesi (300 g) önerilmektedir $(33,34)$.
Araştırmada süt ve süt ürünlerini her gün tüketen hastalarda LDL-K yüksekliği, HDL-K düşüklüğü ve trigliserid yüksekliğinin görülmediği saptanmıştır. Süt ve süt ürünlerinin içerisinde doymuş yağ asitleri bulunmaktadır ve son 3 yıl içinde doymuş yağ asitleri tüketiminin $\mathrm{KAH}^{\prime \prime \prime n ~ p a t o g e n e-~}$ zinde rol oynadığına ilişkin bir karmaşa yaşanmaktadır (12). Çalışma bulgularımızla benzer şekilde, meta analizler son 40 yıl içinde doymuş yağ asitlerinin kalp damar sağlığı için olumsuz etkileri olduğuna ilişkin çalışmaların kanıt düzeylerinin düşük olduğunu belirtmiştir $(35,36)$. Kalp damar hastalıklarının gelişmesinde doymuş yağ asitlerinin rol oynadığına ilişkin sınırlı sayıda kaliteli çalışmalar bulunduğu için, doymuş yağ asitlerin tüketiminin kalp damar hastalıkları riskini artırdığına ilişkin kanıt düzeyi yüksek çalışmalara ihtiyaç vardır. Günümüzde doymuş yağ asitleri ile kalp damar hastalıkları arasında pozitif bir ilişki görülmekle birlikte bazıları koruyucu etkiye sahip olabilir (12). Bizim çalışmamızda süt ve süt ürünleri tüketiminin kan lipit düzeyleri üzerine olan etkisi bu literatür bilgisi ile ilişkilendirilebilir.

Bu çalışmada diyetinde hazır meyve suyunu tüketmeyen hastalarda total kolesterol ve LDL-K yüksekliği ve HDL-K düşüklüğü görülmezken, hazır meyve suyunu ayda bir tüketen ya da diyetinde tüketmeyen hastalarda trigliserid yüksekliğinin olmadığı belirlenmiştir. Ayrıca asitli içecek tüketmeyen ya da ayda bir tüketen hastalarda trigliserid yüksekliğinin olmadığı saptanmıştır. Benzer şekilde literatürde yapılan çalışmalar, şekerli içecekler ile kalp damar hastalıkları arasında anlamlı bir ilişki olduğunu göstermiştir $(37,38)$. Sukroz ve fruktoz tüketimi kan lipit düzeylerini özellikle trigliserid düzeylerini diğer karbonhidratlardan daha fazla yükseltir (21). Çalışma bulgularımız literatür bilgisi ile benzerlik göstermektedir.

Bu araştırmada bir eğitim ve araştırma hastanesinin kardiyoloji kliniğinde tedavi gören hastaların yer alması sınırlılık kabul edildi. Bu nedenle elde edilen sonuçlar sadece örnekleme alınan hastalara genellenebilir. Örneklem büyüklüğünün küçük olması araştırmanın diğer sınırlılığıdır ve daha geniş bir örneklem üzerinde araştırma yeniden yürütülebilir. Araştırma grubumuzun çoğunluğunu yaşlı hastalar oluşturduğu için hafıza faktörü sınırlılık olarak kabul edilebilir. Ayrıca, hastaların yarıdan fazlasının lipit düşürücü tedavi kullanmaları ve birinci derece akrabalarında kalp hastalığı olması araştırma sonuçlarını etkileyebilir.

\section{Sonuç}

Kalp damar hastalıklarının gelişmesinde rol oynayan bağımsız risk faktörlerinden birisi beslenme alışkanlıklarıdır. Bu araştırmada koroner arter hastalarında ara öğün 
tüketiminin trigliserid yüksekliğine; süt ve süt ürünleri ile hazır meyve suyu tüketiminin LDL-K ve trigliserid yüksekliği ile HDL-K düşüklüğüne; balık tüketiminin HDL-K düşüklüğüne ve asitli içecek tüketiminin de trigliserid yüksekliğine neden olduğu bulunmuştur. Bulgular doğrultusunda, KAH açısından yüksek risk taşıyan bireylerin saptanması, sağlıklı yaşam biçimi alışkanlıklarının kazandırılması, bireylerin risk faktörlerinin saptanarak değiştirilebilir risk faktörlerinin düzeltilmesi önerilebilir. Bireylerin risk faktörlerinin ortadan kaldırıması ya da azaltılmasına yönelik; beslenme alışkanlıklarının düzenlenmesi, sağlıklı kilo kontrolünün sağlanması, diyette özellikle kahvaltıda doymuş yağ asitleri içeren besinlerin tüketiminin

\section{Kaynaklar}

1. Sipido KR, Van de Werf F. The growing burden of cardiovascular disease. Eur Heart J 2012;33:1540-1.

2. Vermond RA, Geelhoed B, Verweij N, Tieleman RG, Van der Harst P, Hillege $\mathrm{HL}$, et al. Incidence of atrial fibrillation and relationship with cardiovascular events, heart failure, and mortality: a communitybased study from the Netherlands. J Am Coll Cardiol 2015;66:10007. [CrossRef]

3. Laslett LJ, Alagona Jr P, Clark III BA, Drozda JP, Saldivar F, Wilson $\mathrm{SR}$, et al. The worldwide environment of cardiovascular disease: prevalence, diagnosis, therapy, and policy issues: a report from the American College of Cardiology. J Am Coll Cardiol 2012;60:S1-49. [CrossRef]

4. Türkiye kalp ve damar hastalıklarını önleme ve kontrol programı, risk faktörlerine yönelik stratejik plan ve eylem planı. Sağlık Bakanlığı Temel Sağlık Hizmetleri Genel Müdürlüğü. Ankara: 2008; Sağlık Bakanlığı Yayın No: 743. Erişim: https://sbu.saglik.gov.tr/ Ekutuphane/kitaplar/t14.pdf

5. Hoyert DL, Xu J. Deaths: preliminary data for 2011. Natl Vital Stat Rep 2012;61:1-7.

6. Labarthe DR, Dunbar SB. Global cardiovascular health promotion and diseases prevention 2011 and beyond. Circulation 2012;125:266776. [CrossRef]

7. Akhuemonkhan E, Lazo M. Association between family history of diabetes and cardiovascular disease and lifestyle risk factors in the United States population: The 2009-2012 National Health and Nutrition Examination Survey. Prev Med 2017, 96:129-34. [CrossRef]

8. Van der Ende MY, Hartman MHT, Hagemeijer Y, Meems LMG, de Vries HS, Stolk RP, et al. The LifeLines Cohort Study: Prevalence and treatment of cardiovascular disease and risk factors. Int J Cardiol 2017;228:495-500. [CrossRef]

9. Heper C. Multidisipliner Kardiyoloji. Bursa: Nobel ve Güneş Tıp Yayınevi; 2005. ss.1-97.

10. Crawford M. Kardiyoloji Tanı ve Tedavi. Çevirenler: Erol Ç, Biberoğlu K, Atalar E. 2. Baskı, Ankara: Öncü Basımevi, 2006. ss.1-9.

11. Stewart RAH, Wallentin L, Benatar J, Danchin N, Hagström E, Held C, et al. Dietary patterns and the risk of major adverse cardiovascular events in a global study of high-risk patients with stable coronary heart disease. Eur Heart J 2016;37:1993-2001. [CrossRef]

12. Lacroix S, Cantin J, Nigam A. Contemporary issues regarding nutrition in cardiovascular rehabilitation. Ann Phys Rehabil Med 2017;60:36-42. [CrossRef] azaltılarak besin çeşitliliğinin sağlandığı kahvaltı alışkanlığının yerleştirilmesi ve KAH'ın önlenmesine yönelik sağlıklı beslenme konusunda hemşireler tarafından eğitim ve danışmanlık programlarının verilmesi önerilebilir. Ayrıca ülkemizde geniş bir izleyici kitlesine sahip görsel medya, toplumun $\mathrm{KAH}$ konusunda bilinçlendirilmesinde etkin bir bilgilendirme aracı olarak kullanılabilir. Koroner arter hastalığı, yeterli ve dengeli beslenme, fiziksel aktivite ile ilgili programlar ve spot yayınlar toplumun beslenme alışkanlıklarının düzeltilmesinde ve iyileştirilmesinde, sağlıklı yaşam biçimi alışkanlıklarının oluşturulmasında farkındalık yaratarak hastalık sıklığının ve neden olduğu ölümlerin azaltılmasına katkı sağlayacaktır.

13. Singh RB, Dubnov G, Niaz MA, Ghosh S, Singh R, Rastogi SS, et al. Effect of an Indo-Mediterranean diet on progression of coronary artery disease in high risk patients (Indo-Mediterranean Diet Heart Study): a randomized single-blind trial. Lancet 2002;360:1455-61. [CrossRef]

14. Hatemi H, Turan N, Arık N, Yumuk V. Türkiye obezite ve hipertansiyon taraması sonuçları (TOHTA). Endokr Yön Derg 2002;11:1-15.

15. Jousilahti P, Tuomilehto J, Vartiainene E, Pekkanen J, Puska P. Body weight, cardiovascular risk factors, and coronary mortality. Circulation 1996;93:1372-9. [CrossRef]

16. Çıkım AS, Özbey N, Orhan Y. Relationship between cardiovascular risk indicators and types of obesity in overweight and obese women. J Int Med Res 2004;32:268-73. [CrossRef]

17. Yeşil P, Altıok M. Kardiyovasküler hastalıkların önlenmesi ve kontrolünde fiziksel aktivitenin önemi. Turk J Card Nur 2012;3:39-48. [CrossRef]

18. Erenay SG, Oguz S. Physical activity levels of patients with acute coronary syndrome. Pak J Med Sci 2011;27:149-52.

19. Tokgözoğlu L, Kaya EB, Erol Ç, Ergene O; EUROASPIRE III Türkiye Çalışma Grubu. EUROASPIRE III: Türkiye ile Avrupa'nın karşılaştııılması. Arch Turk Soc Cardiol 2010;38:164-72. Erişim: https://www.journalagent.com/tkd/pdfs/TKDA_38_3_164_172.pdf

20. Lakusić N, Mahović D, Ramqaj T, Cerovec D, Grbavac Z, Babić T. The effect of 3-weeks stationary cardiac rehabilitation on plasma lipids level in 444 patients with coronary heart disease. Coll Antropol 2004;28:623-9.

21. Abraham G. Evaluation of variation in the lipid profile and risk for coronary artery disease in healthy male individuals with respect to age. Int J Res Med Sci 2014;2:551-6. [CrossRef]

22. St-Onge MP, Ard J, Baskin ML, Chiuve SE, Johnson HM, Kris-Etherton P, Varady K. Meal timing and frequency: implications for cardiovascular disease prevention - A scientific statement from the American Heart Association. Circulation 2017;135:e96-121. [CrossRef]

23. Bonow RO, Eckel RH. Diet, obesity and cardiovascular risk. N Engl J Med 2003;348:2057-8. [CrossRef]

24. Szoeke C, Dang C, Lehert P, Hickey M, Morris ME, Dennerstein L, Campbell S. Unhealthy habits persist: The ongoing presence of modifiable risk factors for disease in women. PLoS ONE 2017; 12:e0173603. [CrossRef]

25. Kant AK, Graubard BI. 40-Year trends in meal and snack eating behaviors of American adults. J Acad Nutr Diet 2015;115:50-63. [CrossRef] 
26. Goyal R, Julka S. Impact of breakfast skipping on the health status of the population. Indian J Endocrinol Metab 2014;18:683-7. Erişim: http://www.ijem.in/article.asp?issn=2230-8210;year=2014; volume $=18$;issue $=5$; spage $=683$; epage $=687$; aulast $=$ Goyal

27. Min C, Noh H, Kang YS, Sim HJ, Baik HW, Song WO, et al. Skipping breakfast is associated with diet quality and metabolic syndrome risk factors of adults. Nutr Res Pract 2011;5:455-63. [CrossRef]

28. Deshmukh-Taskar P, Nicklas TA, Radcliffe JD, O'Neil CE, Liu Y. The relationship of breakfast skipping and type of breakfast consumed with overweight/obesity, abdominal obesity, other cardiometabolic risk factors and the metabolic syndrome in young adults: the National Health and Nutrition Examination Survey (NHANES):1999-2006. Public Health Nutr 2013;16:2073-82. [CrossRef]

29. Stote KS, Baer DJ, Spears K, Paul DR, Harris GK, Rumpler WV, et al. A controlled trial of reduced meal frequency without caloric restriction in healthy, normal-weight, middle-aged adults. Am J Clin Nutr 2007;85:981-8. [CrossRef]

30. Farshchi HR, Taylor MA, Macdonald IA. Beneficial metabolic effects of regular meal frequency on dietary thermogenesis, insulin sensitivity, and fasting lipid profiles in healthy obese women. Am J Clin Nutr 2005;81:16-24. [CrossRef]

31. McGrath SA, Gibney MJ. The effects of altered frequency of eating on plasma lipids in free-living healthy males on normal self-selected diets. Eur J Clin Nutr 1994;48:402-7.

32. Titan SM, Bingham S, Welch A, Luben R, Oakes S, Day N, Khaw KT. Frequency of eating and concentrations of serum cholesterol in the Norfolk population of the European prospective investigation into cancer (EPIC-Norfolk): cross sectional study. BMJ 2001;323:1286-8. [CrossRef]
33. Arslan P, Mercangil S, Özel HG, Çıtak Akbulut G, Dönmez N, Çiftçi $\mathrm{H}$, et al. TEKHARF 2003-2004 taraması katılımcılarının genel beslenme örüntüsü ve beslenme alışkanlıkları. Türk Kardiyol Dern Arş 2006;34:331-9. Erişim: https://www.journalagent.com/tkd/pdfs/ TKDA_34_6_331_339.pdf

34. Lee JH, O'Keefe JH, Lavie CJ, Marchioli R, Harris WS. Omega-3 fatty acids for cardioprotection. Mayo Clin Proc 2008;83:324-32. [CrossRef]

35. Chowdhury R, Warnakula S, Kunutsor S, Crowe F, Ward HA, Johnson $\mathrm{L}$, et al. Association of dietary, circulating, and supplement fatty acids with coronary risk: a systematic review and meta-analysis. Ann Intern Med 2014;160:398-406. [CrossRef]

36. de Souza RJ, Mente A, Maroleanu A, Cozma Al, Ha V, Kishibe T, et al. Intake of saturated and trans unsaturated fatty acids and risk of all-cause mortality, cardiovascular disease, and type 2 diabetes: systematic review and meta-analysis of observational studies. BMJ 2015;351:h3978. [CrossRef]

37. de Koning L, Malik VS, Kellogg MD, Rimm EB, Willett WC, Hu FB. Sweetened beverage consumption, incident coronary heart disease, and biomarkers of risk in men. Circulation 2012;125:1735-41. [CrossRef]

38. Fung TT, Malik V, Rexrode KM, Manson JE, Willett WC, Hu FB. Sweetened beverage consumption and risk of coronary heart disease in women. Am J Clin Nutr 2009;89:1037-42. [CrossRef] 